\title{
Omega-3 mechanism of action in inflammation and endoplasmic reticulum stress in mononuclear cells from overweight non-alcoholic fatty liver disease participants: study protocol for the "Brazilian Omega Study" (BROS)—a randomized controlled trial
}

Ellencristina Silva Batista ${ }^{1,2,3,4}$, Thaiane da Silva Rios ${ }^{2,4}$, Vitor Rosetto Muñoz ${ }^{5,4}$, Joyce Santos Jesus ${ }^{3}$, Marcel Monteiro Vasconcelos ${ }^{3}$, Diogo Thimóteo da Cunha ${ }^{6}$, Jose Luis Marques-Rocha ${ }^{7}$, Susana Castelo Branco Ramos Nakandakari ${ }^{2,4}$, Roberta Lara ${ }^{2}$, Adelino Sanchez Ramos da Silva ${ }^{8}$, José Rodrigo Pauli ${ }^{5,4}$, Eduardo Rochete Ropelle ${ }^{5,4}$, Rania Angelina Mekary ${ }^{9,10}$, Leandro Pereira de Moura ${ }^{5}$, Enilton Aparecido Camargo ${ }^{11}$ and Dennys Esper Cintra ${ }^{2,4^{*}}$ (D)

\begin{abstract}
The low-grade inflammation is pivotal in obesity and its comorbidities; however, the inflammatory proteins are out of target for traditional drug therapy. Omega-3 (w3) fatty acids can modulate the downstream signaling of Toll-like receptor (TLR) and tumor necrosis factor-a receptor (TNFa) through GPR120, a G-protein-coupled receptor, a mechanism not yet elucidated in humans. This work aims to investigate if the w3 supplementation, at a feasible level below the previously recommended level in the literature, is enough to disrupt the inflammation and endoplasmic reticulum stress (ER-stress), and also if in acute treatment (3 h) $\omega 3$ can activate the GPR120 in peripheral blood mononuclear cells (PBMC) and leukocytes from overweight non-alcoholic fatty liver disease (NAFL D) participants. The R270H variant of the Ffar4 (GPR120 gene) will also be explored about molecular responses and blood lipid profiles. A triple-blind, prospective clinical trial will be conducted in overweight men and women, aged 19-75 years, randomized into placebo or supplemented (2.2 g of $\omega 3$ [EPA+DHA]) groups for 28 days. For sample
\end{abstract}

\footnotetext{
* Correspondence: dcintra@yahoo.com

Ellencristina Silva Batista and Thaiane da Silva Rios worked equally. Enilton Aparecido Camargo and Dennys Esper Cintra equally coordinate the study 2Laboratory of Nutritional Genomics, School of Applied Sciences, University of Campinas, Pedro Zaccaria, 1300 Zip, Limeira 13484-350, Brazil

${ }^{4}$ Lipids and Nutrigenomics Research Center, School of Applied Sciences, University of Campinas, Limeira, Brazil

Full list of author information is available at the end of the article
}

C C The Author(s). 2021 Open Access This article is licensed under a Creative Commons Attribution 4.0 International License, which permits use, sharing, adaptation, distribution and reproduction in any medium or format, as long as you give appropriate credit to the original author(s) and the source, provide a link to the Creative Commons licence, and indicate if changes were made. The images or other third party material in this article are included in the article's Creative Commons licence, unless indicated otherwise in a credit line to the material. If material is not included in the article's Creative Commons licence and your intended use is not permitted by statutory regulation or exceeds the permitted use, you will need to obtain permission directly from the copyright holder. To view a copy of this licence, visit http://creativecommons.org/licenses/by/4.0/ The Creative Commons Public Domain Dedication waiver (http://creativecommons.org/publicdomain/zero/1.0/) applies to the data made available in this article, unless otherwise stated in a credit line to the data. 


\begin{abstract}
calculation, it was considered the variation of TNFa protein and a 40\% dropout rate, obtaining 22 individuals in each group. Volunteers will be recruited among patients with NAFLD diagnosis. Anthropometric parameters, food intake, physical activity, total serum lipids, complete fatty acid blood profile, and glycemia will be evaluated preand post-supplementation. In the PBMC and neutrophils, the protein content and gene expression of markers related to inflammation (TNFa, MCP1, IL1ß, IL6, IL10, JNK, and TAK1), ER-stress (ATF1, ATF6, IRE1, XBP1, CHOP, elF2a, elF4, HSP), and $\omega 3$ pathway (GPR120, $\beta$-arrestin2, Tab1/2, and TAK1) will be evaluated using Western blot and RTqPCR. Participants will be genotyped for the R270H (rs116454156) variant using the TaqMan assay. It is hypothesized that attenuation of inflammation and ER-stress signaling pathways in overweight and NAFLD participants will be achieved through $\omega 3$ supplementation through binding to the GPR120 receptor.
\end{abstract}

Trial registration: ClinicalTrials.gov \#RBR-7x8tbx. Registered on May 10, 2018, with the Brazilian Registry of Clinical Trials.

Keywords: Overweight, GPR120, Omega-3, Inflammation, Endoplasmic reticulum stress, NAFLD

\section{Background}

The world is losing the war against obesity [1], a phenomenon endorsed by ineffective therapeutic drugs or unsuccessful weight loss maintenance after bariatric surgery [2]. It is well recognized that excess saturated fatty acids from ultra-processed foods, de novo lipogenesis, and visceral adipose tissue efflux can activate and intensify pro-inflammatory signaling and endoplasmic reticulum stress response (ER-stress) while reducing systemic insulin sensitivity [3-6]. The hyperglycemiainduced by impaired glucose uptake by the skeletal muscle and increased hepatic gluconeogenesis and glycogenolysis [5-9] lead to non-alcoholic fatty liver disease (NAFLD) development, common obesity-associated comorbidity [6].

Monocytes and lymphocytes play a pivotal role in inflammation and may be actively involved in NAFLD development or progression $[10,11]$. Leukocytes are sensitized by inflammatory proteins and respond to changes in the levels of the fatty acid by regulating a wide gene network, including those involved in immune response and lipid metabolism [12]. Because NAFLD is directly associated with increased plasma lipid levels, it is possible that data obtained from isolated peripheral blood mononuclear cells (PBMCs) could reflect the in vivo condition and contribute to biological and clinical insights into the human NAFLD process $[10,11]$. ER-stress and activation of the unfolded protein response (UPR) have been linked to a variety of inflammatory and stress signaling systems mainly mediated by cJUN N-terminal-Kinase (JNK) and inositol-requiring enzyme $1 \alpha($ IRE $1 \alpha)$ proteins. Inflammatory and ER-stress signaling in PBMC seems to reflect changes occurring in metabolically active organs such as the adipose tissue, skeletal muscle, and liver [10, 11].

During obesogenesis, the liver can be affected by inflammation triggered by TLR and sustained by cytokines and its receptors such as tumor necrosis factor-alpha (TNFo), interleukins (IL) 1, and IL6 [13-15]. Both intracellular pathways converge to the phosphorylation of TAK1 (TGF $\beta$-activated kinase1), which activates the canonical NFkB pathway [16-18]. Thus, the nonpharmacological approach of omega-3 $(\omega 3)$ fatty acids emerges as a potential strategy to control the systemic pro-inflammatory tonus once $\omega 3$ attenuates the TAK1 activity $[4,17,19-22]$.

Since the 1970s, $\omega 3$ has been used and evidenced as an anti-inflammatory due to changes in the $\omega 6: \omega 3$ ratio [23, 24]. However, during the 2000s decade (20002010), some G-protein-coupled receptor (GPCR) members were identified as possible fatty acids' receptors. Among them, GPR120 was recognized as $\omega 3$ being its major activator [25]. Then, in 2010, a hallmark work of Oh et al. [17] showed the detailed molecular mechanism of $\omega 3$ as an anti-inflammatory nutrient. On the cell surface, $\omega 3$ fatty acids (eicosapentaenoic-EPA-[C20:5] or docosahexaenoic-DHA-[C22:6]) bind to GPR120, while attracting the intracellular beta-arrestin 2 (ßarr2) protein and inhibiting TAK1 phosphorylation in hepatocytes and adipocytes. This mechanism appears to be reinforced when Barr2 also recruits the NLPR3 (NOD-, LRR-, and pyrin domain-containing protein 3) protein, disrupting the inflammasome, a structure involved in the

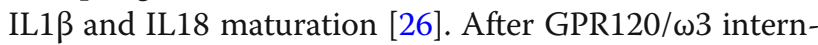
alization induced by $\beta$ arr2, free $\omega 3$ in the cytosol can be derived into pro-resolutive mediators such as resolvins, maresins, and protectins, which are well recognized $\omega 3$ subcompounds [27, 28]. The dynamic antiinflammatory pleiotropism orchestrated by $\omega 3$ is strengthened when this molecule activates the peroxisome proliferatoractivated receptor-gamma (PPAR $\gamma$ ), in which it blocks the nuclear translocation of NFkB [18].

Nonetheless, some clinical trials were not able to show any $\omega 3$ benefits in human health $[29,30]$. Some 
guidelines for the management of cardiovascular diseases demonstrate weak evidence or do not recommend $\omega 3$ fatty acids as weak evidence or without the strength of recommendation [31, 32]. Therefore, we propose an investigation to understand the reason for this "conundrum" in $\omega 3$ knowledge. The present study aims to clarify the recognized but not solved biases, commonly found in studies such as [1] uncertified $\omega 3$ fatty acid content in capsules or fish's flesh, [33] [2] uncontrolled bioavailability from gut to the bloodstream and bioaccessibility from the blood to cell incorporation/uptake, [3] $\omega 3$ discrepant doses [4], [4] $\omega 3$ EPA: DHA blend, [5] incorrect placebo choices $[34,35]$, and $[6]$ the presence of GPR120 polymorphism [36].

Here, overweight/obese NAFLD patients are chosen in such a way to deviate from cardiovascular studies' possible biases. Thus, they will be monitored on their inflammatory and ER-stress pathways in PBMCs and neutrophils.

\section{Subjects and methods}

\section{Study design and settings}

This is a triple-blinded (investigators, statistical analysts, and participants), single-centered, randomized placebocontrolled, prospective intervention trial. This protocol is written following the Standard Protocol Items: Recommendations for Interventional Trials (SPIRIT) checklist [37]. The study is designed to investigate the molecular action mechanisms of $\omega 3$ as antiinflammatory and anti-ER stress through GPR120 receptor in peripheral blood mononuclear cells (PBMC) and leukocytes of overweight and obese subjects with visceral obesity and non-alcoholic fatty liver disease (NAFLD). The study protocol was approved by the Ethics Committee of the Federal University of Sergipe (\#80476517.2.0000.5546) and registered at the Brazilian Registry of Clinical Trials (\#RBR-7x8tbx), on May 10, 2018, retrospectively registered: https://ensaiosclinicos.gov.br/rg/RBR-7x8tbx. All outpatients will be informed by study design before signing the informed consent form.

In the first part of the intervention (acute measurement [ $3 \mathrm{~h}$ after the first capsule intake]), the surrogate outcomes will be [1] $\omega 3$ fatty acid concentration in bloodstream, [2] association between GPR120 and Barr2 proteins, and [3] $\omega 3$ fatty acid concentration into PBMCs. In the second part, after chronic treatment (28 days of supplementation), the primary outcome will be considered the reduction (upper to 10\%) in the TNF $\alpha$ and IL6 protein contents in PBMCs. Both parts of the intervention will be carried out in PBMC and leukocytes. Outcomes such as body weight, waist circumference, and glycemia will not be considered due to short supplementation time and study aim.

\section{Eligibility}

Eligibility criteria will be overweight or obese subjects (BMI $>24.9 \mathrm{~kg} / \mathrm{m}[2]$ ), with visceral adiposity (waist circumference $>80 \mathrm{~cm}$ for women and $>94 \mathrm{~cm}$ for men) [38], the age range of 19-75 years. Outpatients, who were for the first time consulted by an expert physician, from January 2016 to December 2018, at the Hepatology Clinic of the Federal University of Sergipe, Aracaju, Brazil, were diagnosed with non-alcoholic fatty liver disease (NAFLD) using ultrasound and laboratory tests. The exclusion criteria will consider any history of chronic liver diseases, such as viral or drug hepatitis, confirmed Wilson disease, primary hemochromatosis, suffering from hyper or hypothyroidism, cancers, diabetes mellitus type 1 , diabetes mellitus type 2 in insulin therapy, obesity due to excessive use of corticosteroids, Cushing's syndrome, patients with chronic infections, autoimmune diseases, in abuse of alcohol, in use of hepatotoxic drugs, pregnant, and breastfeeding women. Additionally, patients who are not able to participate in the standardized anthropometric evaluation in the study, such as patients with amputated limbs and those who cannot answer the questionnaires, such as the ones with neurological diseases, will not be eligible. Patients with acute myocardial infarction and stroke in the last 5 years are precluded from participating. Individuals taking antiinflammatory drugs and who in the last 3 months before the study made use of nutritional supplements containing oils, fats, or fatty acids will be excluded. Those who had a weight loss of more than $10 \%$ of body weight in the last 3 months will also be excluded.

\section{Sample size calculation}

The sample size calculation was carried out using the $G$ * Power 3.1.9.2 software, and the following values and information were considered: [1] two groups (control and treatment) and [2] effect size $d=1.15$ considering the variation of TNF $\alpha / \beta$ actin protein observed in the study by Huang et al. (2016) [39]. In this study, the control group showed $0.45 \pm 0.04$ (average of arbitrary units \pm standard deviation) for TNF $\alpha$ while the telmisartan treated group showed $0.36 \pm 0.04$ [39]. As in the reference study [39], three types of drugs were used (telmisartan, cyclosporine, and 4-aminopyridine), and the least effective was chosen, understanding that eating will have a possible minor effect concerning hypertensive drugs. This procedure may reduce type II error, [3] type I error $\alpha=0.05$, and [4] sampling power $(1-\beta)=85 \%$ [5]. The sample size needed was 16 individuals in each group. However, considering a $40 \%$ dropout rate, it will be selected 22 per group.

\section{Recruitment}

Patients' volunteers will be recruited from the Hepatology Clinic via a phone call to interview and screen 
participants according to inclusion and exclusion criteria. For each participant, there will be a maximum of 10 attempts to make calls upon the first contact asking participants to fill the questionnaire; if he/she cannot fill the questionnaire, another ten attempts to conduct the phone interview will be made. For a participant to be eligible, one has to agree to answer a screening questionnaire based on the Surveillance of Risk Factors and Protection Survey for Chronic Non-Communicable Diseases by Telephone Interviews (Vigitel) [40]. Then, another interview will be scheduled to confirm the data obtained by phone and the nutritionist will explain the study procedures and consent form to the participants. Participants who agree to participate in the study will sign the consent form and go through the initial assessment. Then, 44 individuals will be randomly drawn for participation in the study, and subsequently, they will be randomized into the study groups: placebo and $\omega 3$. To maintain confidentiality, each participant will be codified with a number, and only one co-author of the study will have the complete name and data of the participants.

\section{Assessments to randomization}

Before the randomization, an assessment will be made, including a questionnaire about sociodemographic data, alcoholism, smoking, prescription drugs, anthropometric assessment, and body composition (through bioelectric impedance). A blood sample collection will be performed for assessment of plasma glucose levels, insulin, ferritin, glycated hemoglobin, total cholesterol, HDLc and LDLc lipoproteins, triacylglycerol, alanine aminotransferase, aspartate aminotransferase, and C-reactive protein at the Hepatology Clinic.

\section{Randomization}

The distribution between groups, placebo or $\omega 3$, will be randomly assigned into groups, placebo or $\omega 3$. A sequence number will be generated by SPSS 25.0 under the ratio of 1:1. The numbers will be placed in a sealed envelope and randomly distributed to the participants. After, participants will be listed in ascending order based on biochemical and anthropometric variables, grouped in blocks of two, and then allocated to each of the groups in an equalized manner to ensure group homogeneity. All eligible individuals by the users of the selection will receive a unique and non-transferable code. An independent data manager, who is not involved in clinical practice or patient recruitment, will create the randomization sequence.

\section{Interventions}

\section{Omega-3 and placebo}

The $\omega 3$ capsules were donated by Naturalis ${ }^{\circ}$, Nutrition and Pharma Company, São Paulo, Brazil. Each capsule contains $1 \mathrm{~g}$ of fish oil in the form of triglycerides, which is equivalent to about $\approx 750 \mathrm{mg}$ of $\omega 3$ ([EPA-190 mg; DHA-550 mg], Table 1). The quality of the oil was certified by mass spectrometry (as shown by the Omega-3 determination method below). The heavy metals are under a minimum limit allowed daily intake (arsenic $[<$ $0.1 \mathrm{ppm}]$, cadmium $[<0.01 \mathrm{ppm}]$, lead $[<0.05 \mathrm{ppm}]$, and mercury $[<0.005 \mathrm{ppm}])$. Placebo pills consist of $1 \mathrm{~g}$ of mineral oil and were donated by the Catalent Pharma, Inc., Company, Sorocaba, Brazil.

\section{Procedures}

Figure 1A illustrates the simplified acute and chronic intervention design, and Fig. 1B illustrates the overall design and subject flow through the study. Participants may be withdrawn from the study at their request. Upon the first meeting, after being fully informed about the study and all risk factors, patients will be asked to sign the informed consent form. At this moment, the clinical questionnaire will be administrated. Instructions on a blood collection and body bioelectrical impedance test will be given. A second meeting will follow to conduct the randomization of the groups. Body composition and anthropometric profiles will be assessed, and the blood will be collected from all participants. Participants will be instructed to fill three dietary records. After randomization and $12 \mathrm{~h}$ of fasting, in the third meeting, the acute supplementation phase will begin. Initially, participants will perform the bioelectrical impedance test before the blood collection and before the ingestion of three capsules of placebo or three capsules of $\omega 3$ (totaling $2.2 \mathrm{~g}$ of $\omega 3$ [EPA-570 mg, DHA-1650 mg]), depending on the group in which they were randomized. In the meantime, because they have to wait for $3 \mathrm{~h}$ for the second blood collection to assess the $\omega 3$ bioavailability and ability to activate the GPR120 receptor, a 24-h recall (R24h), three dietary records will be administered and physical activity level, and anthropometric profiles will be evaluated. At the end of this meeting, an amber plastic flask protecting the capsules from light and oxygen will be provided to each participant, containing capsules available for 28 days of supplementation (3 caps/day or $2.2 \mathrm{~g}$ of $\omega 3)$. Two days after this last meeting, the patients will report by phone call their R24h. At the last meeting and after $12 \mathrm{~h}$ fasting, all these assessments will be repeated.

\section{Blinding}

The practitioners, participants, outcome assessors, and statisticians will be kept blinded to treatment allocation throughout the trial. No toxic/adverse effects, beyond eructation, have been reported in previous studies using Omega-3 in a similar dose adopted by this study. Capsules will be prepackaged into opaque and identical 
Table 1 Fatty acid composition of a capsule containing $1 \mathrm{~g}$ of pure fish oil

\begin{tabular}{|c|c|c|}
\hline Carbons/insaturations/w-position & Nomenclature (IUPAC) & $\mathrm{mg} / \mathrm{g}$ \\
\hline C8:0 & Octanoic acid, methyl ester & 0.0411 \\
\hline C10:0 & Decanoic acid, methyl ester & 0.0564 \\
\hline C14:0 & Methyl tetradecanoate & 0.3816 \\
\hline C16:0 & Hexadecanoic acid & 1.4015 \\
\hline C16:1 & Hexadecenoic acid & 0.6626 \\
\hline C18:0 & Methyl stearate & 1.8020 \\
\hline C18:1 (w9) & Octadecenoic acid & 3.6400 \\
\hline C18:2 (w6) & Octadecadienoic acid & 0.3841 \\
\hline C18:3 (w3) & Octadecatrienoic acid & 0.1981 \\
\hline C19:0 & Nonadecanoic acid & 0.1619 \\
\hline C20:1 & cis-11-Eicosenoic acid & 3.5847 \\
\hline C20:1 & cis-13-Eicosenoic acid & 0.5901 \\
\hline$C 20: 2(\omega 3)$ & 8,11-Eicosadienoic acid & 0.4160 \\
\hline$C 20: 2(\omega 6)$ & 11,14-Eicosadienoic acid & 0.4051 \\
\hline$C 20: 3$ & Eicosatrienoic acid & 0.2284 \\
\hline C20:4 (w6) & Eicosatetraenoic acid & 1.6491 \\
\hline $\mathrm{C} 21: 0$ & Heneicosanoic acid & 0.3023 \\
\hline C20:5 (w3) & Eicosatetraenoic acid & 19.0560 \\
\hline $\mathrm{C} 22: 0$ & Docosanoic acid & 0.8260 \\
\hline C22:1 & Docosenoic acid & 6.3434 \\
\hline$C 22: 4(\omega 6)$ & Docosatetraenoic acid & 0.3351 \\
\hline$C 22: 6(\omega 3)$ & Docosatetraenoic acid & 55.0547 \\
\hline \multirow[t]{6}{*}{ C24:0 } & Tetracosenoic acid & 2.4781 \\
\hline & $\Sigma S A T$ & 7.45 \\
\hline & $\Sigma \mathrm{MONO}$ & 14.8208 \\
\hline & $\sum$ POLY & 77.7266 \\
\hline & $\sum \omega 6$ & 2.7734 \\
\hline & $\sum \boldsymbol{\omega} 3 *$ & 74.3087 \\
\hline
\end{tabular}

IUPAC International Union of Pure and Applied Chemistry, $\omega$ Omega, $\Sigma$ sum, SAT saturated fatty acids, MONO monounsaturated fatty acids, POLY polyunsaturated fatty acids. *EPA, DHA plus other $\omega 3$ species

containers labeled with codes by a local pharmacy, with the investigator's details and supplementation instructions. This ensures the total blinding of both the participants and investigators. In the event of adverse events, clinicians will be able to unblind participants if they consider this necessary.

\section{Safety, compliance monitoring, and participant retention}

During follow-up, once a week, participants will report adverse events by phone, which is expected such as eructation, followed by uncomfortable gastric odor. The weekly contact will also promote participant retention to complete the study. In the case of significant adverse effects, the participant will be evaluated by the medical service from the hospital. Together with medical service, the nutritionist leader of this project will be responsible for participant stopping. Treatment compliance will be assessed by the plasma fatty acid content of patients at the beginning and the end of the experiment, which will be analyzed using a gas-chromatograph coupled to a mass spectrometer $[41,42]$. See the experimental design of the interventions in Fig. 1 and the detailed schedule of assessments depicted in Table 2.

\section{Anthropometric data}

Anthropometric (body weight, height, waist-to-height ratio, waist and neck circumferences, and four skin folds) and body composition (electric bioimpedance) data will be assessed at baseline and postintervention, following respective standardized guidelines and cut-offs [38, 43-46]. 


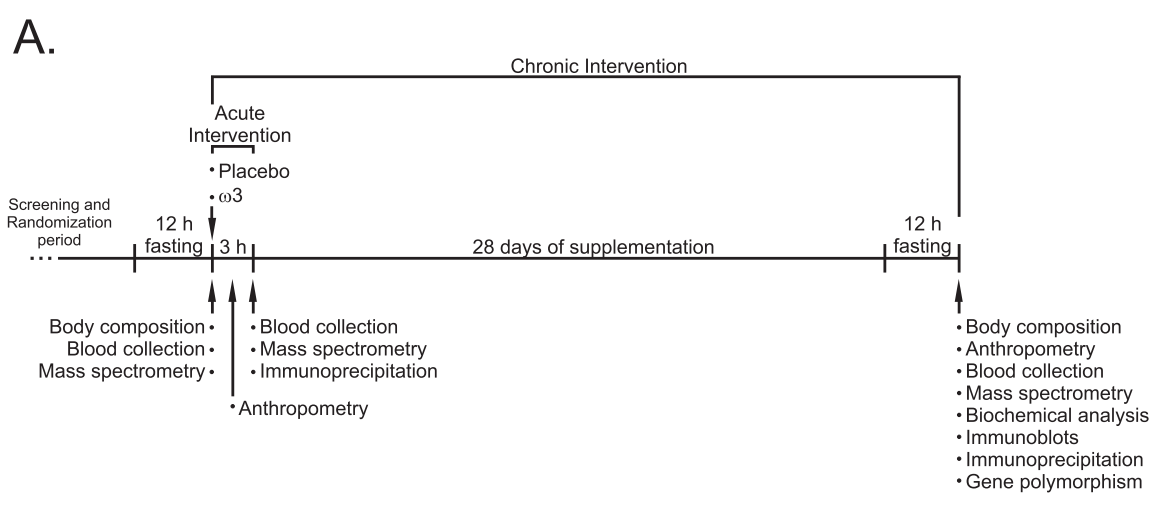

B.

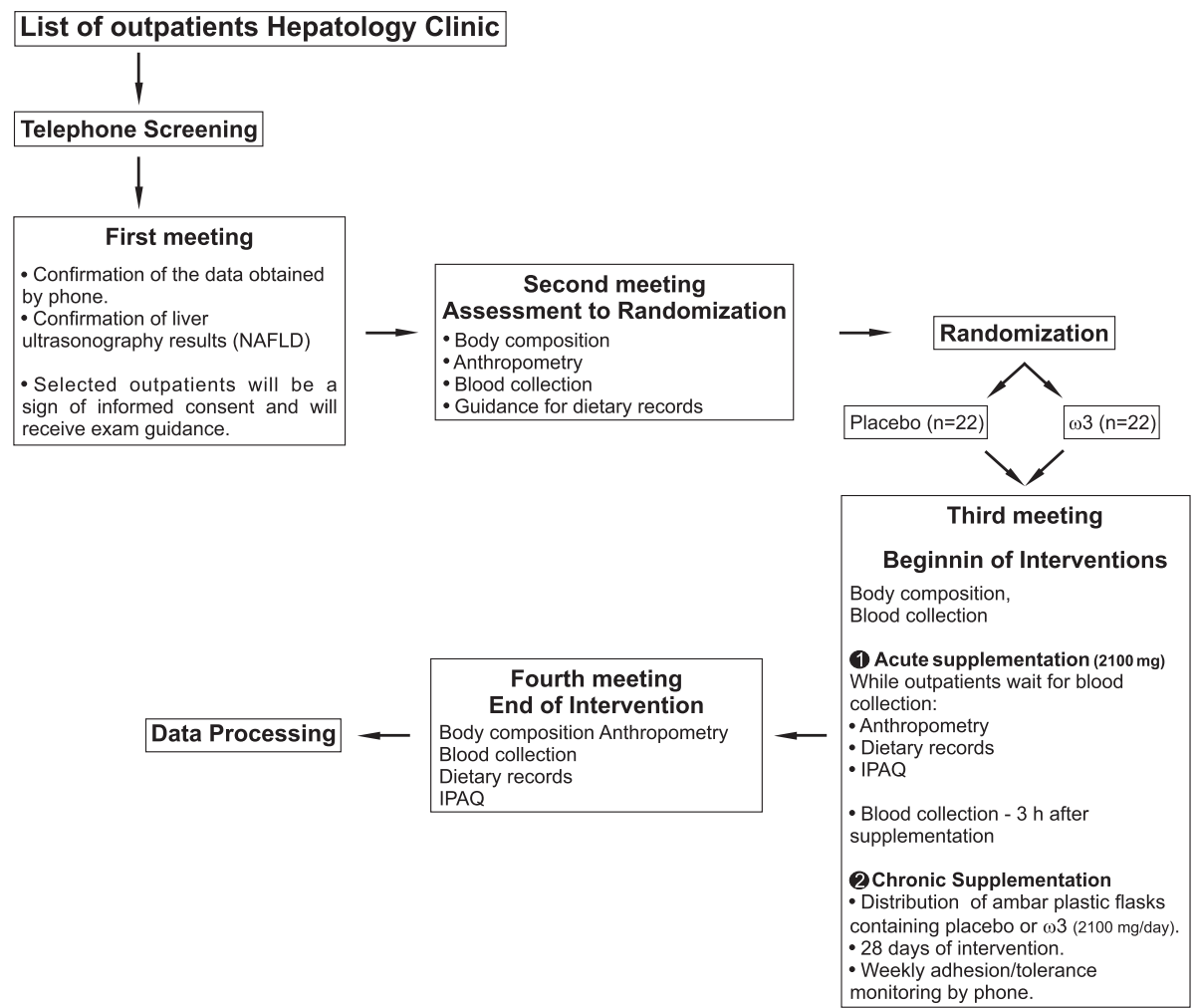

Fig. 1 Experimental interventions scheme and detailed subject flow. A After the screening and randomization period, the selected participants will be fasting for $12 \mathrm{~h}$. At the hospital service, body composition will be carried out, followed by the blood collection for biochemical and mass spectrometry analysis. Immediately, participants will take their placebo or $\omega 3$ capsules and wait for $3 \mathrm{~h}$. Anthropometric measurements will then be performed, the same collections will be repeated, and another part of the blood will be separated to an immunoprecipitation test to verify the association between GPR120 and Barr2 proteins. After 30 days of supplementation, all measurements will be repeated with the inclusion of immunoblot blood tests and polymorphic GPR120 gene analysis. B Detailed flow through the study. w3 Omega-3. IPAQ International Physical Activity Questionnaire

\section{Food intake}

Food intake data will be obtained before and after supplementation using two R24h and three dietary records using the photographic record. Two R24h will be performed on non-consecutive days during the week and one at the weekend. The two R24h will be held on non-consecutive days, one in the third meeting and another after 2 days by phone call. The intake of each food item will be transformed into daily consumption (grams or milliliters). After, total caloric intake, nutrients (carbohydrates, proteins, fats, vitamins, and minerals) and other specific components (fibers, carotenoids, sugars, and fatty acids) will be calculated according to the nutritional composition of each source food provided priority by the Brazilian Food Composition List (TACO) [47] and by the 
Table 2 Schematic schedule of enrolment

\begin{tabular}{|c|c|c|c|c|c|c|c|c|c|c|c|}
\hline \multicolumn{12}{|c|}{ STUDY PERIOD } \\
\hline & \multirow[t]{2}{*}{ Enrolment } & \multicolumn{2}{|c|}{ Randomization } & & \multicolumn{6}{|c|}{ Intervention } & \multirow{2}{*}{$\frac{\text { Post-intervention }}{\text { Meeting } 4}$} \\
\hline & & \multirow[t]{2}{*}{ Meeting 1} & \multirow[t]{2}{*}{ Meeting 2} & & \multicolumn{2}{|c|}{ Meeting 3} & \multicolumn{4}{|c|}{ Home } & \\
\hline & & & & & & & Day 7 & Day 14 & Day 21 & Day 28 & \\
\hline Timepoint & $\overline{t-4}$ & $t-3$ & $t-2$ & $\sqrt{t-1}$ & Oh & $3 \mathrm{~h}$ & & & & & $t+1$ \\
\hline $\begin{array}{l}\text { Check the list of } \\
\text { outpatients }\end{array}$ & & & & & & & & & & & \\
\hline $\begin{array}{l}\text { Omega-3 fatty acids } \\
\text { determination from } \\
\text { capsules }\end{array}$ & & & & & & & & & & & \\
\hline $\begin{array}{l}\text { Telephone } \\
\text { Screening }\end{array}$ & & & & & & & & & & & \\
\hline $\begin{array}{l}\text { Confirm the data } \\
\text { obtained by } \\
\text { telephone }\end{array}$ & & & & & & & & & & & \\
\hline $\begin{array}{l}\text { Guidance for blood } \\
\text { collection }\end{array}$ & & & & & & & & & & & \\
\hline $\begin{array}{l}\text { Guidance for dietary } \\
\text { records }\end{array}$ & & & & & & & & & & & \\
\hline Body composition & & & & & & & & & & & \\
\hline Anthropometric & & & & & & & & & & & \\
\hline IPAQ & & & & & & & & & & & \\
\hline Dietary record & & & & & & & & & & & \\
\hline Blood collection & & & & & & & & & & & \\
\hline $\begin{array}{l}\text { Blood biomarkers } \\
\text { analysis }\end{array}$ & & & & & & & & & & & \\
\hline $\begin{array}{l}\text { Fatty acids } \\
\text { determination from } \\
\text { plasma }\end{array}$ & & & & & & & & & & & \\
\hline $\begin{array}{l}\text { Fatty acids } \\
\text { determination from } \\
\text { cells }\end{array}$ & & & & & & & & & & & \\
\hline Statistical analysis & & & & & & & & & & & \\
\hline $\begin{array}{l}\text { Call by Phone to } \\
\text { arrange the meeting } \\
\text { to intervention }\end{array}$ & & & & & & & & & & & \\
\hline $\begin{array}{l}\text { Safety, compliance } \\
\text { monitoring, and } \\
\text { participant retention }\end{array}$ & & & & & & & & & & & \\
\hline PBMC and isolation & & & & & & & & & & & \\
\hline $\begin{array}{l}\text { Fatty acids } \\
\text { determination from } \\
\text { blood and cells }\end{array}$ & & & & & & & & & & & \\
\hline $\begin{array}{l}\text { Immunoblotting and } \\
\text { immunoprecipitation } \\
\text { analysis }\end{array}$ & & & & & & & & & & & \\
\hline Gene expression & & & & & & & & & & & \\
\hline $\begin{array}{ll}\text { Gpr120 } & \text { gene } \\
\text { polymorphism } \\
\text { R270H variant }\end{array}$ & & & & & & & & & & & \\
\hline
\end{tabular}

Household Budget Survey data (IBGE, 2010) [48] when food is not found in the first one, with the help of Microsoft Excel (v. 2016) and SPSS (v. 22) software to organize and analyze the data. The values of energy consumption, nutrients, food groups according to nutritional similarity, and food groups according to the degree of industrial processing derived from the four 24hRs will be disattenuated (corrected by intra- individual variability), generating unique values for each item. This will be achieved through the PC-SIDE program (Department of Statistics, Iowa State University, Iowa, USA) developed by the National Research Council and Iowa State University [49]. Moreover, consumption values will be adjusted for energy intake by the residual method [50]. The outpatients will be instructed not to change their dietary patterns. 


\section{Physical activity}

The IPAQ (International Physical Activity Questionnaire) validated for the Brazilian population will be used to assess physical activity levels [51]. After being measured, the outpatients will be instructed not to change their physical activity patterns.

\section{Prescribed medications}

As described in the eligibility session, only patients under anti-inflammatory therapy will be excluded. There are no restrictions for any other medications; however, any alteration on prescribed medications will need to be immediately communicated.

\section{PBMC isolation}

After blood collection into heparinized tubes, the samples will be prepared with the use of histopaque-1077 (Sigma, St. Louis, MO, USA). In brief, $15 \mathrm{~mL}$ of the blood will be carefully layered onto $15 \mathrm{~mL}$ of histopaque. Bands containing the mononuclear cells, leukocytes, and red cells will be collected separately. The PBMCs will be washed with saline, centrifuged, and the supernatant removed [52]. This step will be repeated twice, and three parts of the cell suspension will be destined for immunoblotting/immunoprecipitation, RT-qPCR, and lipid profile analysis. Neutrophils and red blood cells will be lysed using a standard lysis buffer and re-suspended in Trizol $^{\circ}$ reagent (Life Technologies), storing at $-80{ }^{\circ} \mathrm{C}$ for RT-qPCR analysis.

\section{Immunoblotting and immunoprecipitation analysis}

After isolation, PBMCs and neutrophils will be immediately homogenized in solubilization buffer at $4{ }^{\circ} \mathrm{C}[1 \%$ Triton X-100, $100 \mathrm{mmol} / \mathrm{L}$ Tris-HCl (pH 7.4), 100 $\mathrm{mmol} / \mathrm{L}$ sodium pyrophosphate, $100 \mathrm{mmol} / \mathrm{L}$ sodium fluoride, $10 \mathrm{mmol} / \mathrm{L}$ EDTA, $10 \mathrm{mmol} / \mathrm{L}$ sodium orthovanadate, $2.0 \mathrm{mmol} / \mathrm{L}$ PMSF, and $0.1 \mathrm{mg}$ aprotinin $/ \mathrm{mL}$ ]. For these cells or plasma proteins, the quantification of total protein will be carried out according to the bicinchoninic acid method [53]. Samples containing 50 $\mu \mathrm{g}$ of protein extracts will be separated by SDS-PAGE, transferred to nitrocellulose membranes, and blotted with antibodies against inflammatory markers: TNF $\alpha$, MCP1, IL1 $\beta$, IL6, IL10, JNK, and TAK1; ER-stress markers: ATF1, ATF6, IRE1, XBP1, CHOP, eIF2 $\alpha$, and eIF4; and $\omega 3$ pathway markers: GPR120, $\beta$ arr2, and $\mathrm{TAB} 1 / 2$. In some experiments, the association between GPR120 and Barr2 or Barr2 and TAB1/2 will be evaluated by performing immunoprecipitation. Samples of total protein extracts containing $200 \mu \mathrm{g}$ of protein will be used for immunoprecipitation with antibodies against GPR120, $\beta$ arr2, or TAB1/2 and protein G-sepharose at $4{ }^{\circ} \mathrm{C}$ overnight, followed by SDS/PAGE and will be transferred to nitrocellulose membranes and blotting with respective antibodies. The bands will be labeled by chemiluminescence and its visualizations performed by GBOX-Chemi-XX6 from Syngene ${ }^{\circ}$ (Cambridge, Eng).

\section{Gene expression}

Leukocytes and PBMCs re-suspended in Trizol $^{\circ}$ reagent (Life Technologies) will be submitted to RNA extraction according to the manufacturer's instructions. Reverse transcription reaction will be performed using a commercially available set of High Capacity cDNA Archive Kit (Applied Biosystems, USA). The cDNA will be prepared from $1 \mu \mathrm{g}$ of mRNA, with random hexamer primers, for $10 \mathrm{~min}$ at $25^{\circ} \mathrm{C}, 2 \mathrm{~h}$ at $37^{\circ} \mathrm{C}$, and $4{ }^{\circ} \mathrm{C}$ thereafter on a PCR thermocycler Gene (Applied Biosystems, USA). The resulting CDNA will be diluted to a final concentration of $5 \mathrm{ng} / \mu \mathrm{L}$ to constitute a matrix in further experiments. For real-time quantitative PCR amplification, the TaqMan system (Thermo Scientific ${ }^{\circ}$ ) using specific probes and primers (Tnfo, Il1 $\beta, I l 6$, Il10, Ire1, Perk, and Atf6) gene evaluation will be used, and Gapdh will be used as a constitutively expressed gene in these cells. The 7500 real-time qPCR equipment (Applied Biosystems ${ }^{\circ}$ ) will perform fluorescence readings. Expression levels of the target gene transcribed in each sample will be calculated by the comparative Ct method (formula $2^{\Delta \mathrm{Ct}}$ ) after normalization with the endogenous gene (Gapdh) from Applied Biosystems .

\section{Gpr120 gene polymorphism-R270H variant}

The GPR120 gene variant R270H (rs116454156) polymorphism will be genotyped using the Taqman allelic discrimination technique in the 7500 real-time qPCR equipment (Applied Biosystems $s^{\circ}$ ), following the method proposed by Ichimura et al. (2012) [36].

\section{Omega-3 fatty acid determination from capsules, blood, and cells}

Fifty $\mu \mathrm{L}$ of oil obtained directly from $\omega 3$ capsules will be submitted to saponification and esterification following the method of Hartman and Lago [54]. To determine the free fatty acid profile from the blood, $150 \mu \mathrm{L}$ of the plasma will be directly methylated according to the previously described procedure (Shirai et al., 2005) [55]. Fatty acid methyl esters will be analyzed using a gas chromatograph coupled to the mass spectrometer (model GCMS-QP2010 Ultra; Shimadzu) and a fusedsilica capillary Stabilwax column (Restek Corporation, U.S.) with dimensions of $30 \mathrm{~m} \times 0.25 \mathrm{~mm}$ internal diameter coated with a $0.25-\mu \mathrm{m}$-thick layer of polyethylene glycol. The experimental conditions will be followed by the method described by Cintra et al., 2012 [4]. 


\section{Data treatment and statistical aspects}

A steering committee will be organized for trial supervision. The process of data collection and management will be monitored by them. The committee may recommend and request the principal investigator to make some changes to the plan. To increase the security and data quality, the records will be inputted at the bank by one person and checked by another one. Data analysis will be performed according to the intention-to-treat principles [56]. The software Statistical Package for Social Sciences (SPSS), v. 22.0, will be used for data entry and analysis. Statistical analysis will be performed through descriptive analysis, with numerical variables expressed as the mean and standard deviation (SD) or median and interquartile range. All data will be subjected to the ShapiroWilk normality test. First, a two-way analysis of variance will be performed to check intra- and intergroup differences. Time will be added as a repeated factor, treatment as an independent factor, and the other variables (e.g., anthropometric data, food intake, blood analysis) as covariates.

The paired Student's $t$ test or Wilcoxon's test will be used to compare the time effects. The Student's $t$ test and Mann-Whitney $U$ test will be used to investigate group differences (placebo and treatment). All tests will be considered significative $P<0.05$. After trial completion, the principal investigator (PI) will be responsible for data archiving and preservation. Only investigators can access data. The PI will be responsible to terminate the trial at any moment.

\section{Reporting of the study results}

At the end of the experimental period, the results of the biochemical and anthropometric analysis will be delivered to patients in person. Also, at the end of the study, a meeting will be planned to discuss the results individually. Absent patients will receive their summarized results by email.

\section{Discussion}

Due to the multifaceted $\omega 3$ 's ability to modulate inflammation $[17,22,26,28]$, it is not surprising to find $\omega 3$ as a panacea; however, this most widely investigated nutrient still has many unsolved questions. Several noncontrolled biases and confounding factors compromise the real interpretation of $\omega 3$ actions, even those well controlled and with a high number of participants [57]. To elucidate some points related to $\omega 3$ fatty acids in human health, we designed a triple-blinded, randomized placebo-controlled intervention trial. This study has an experimental design, followed by an acute and chronic intervention in overweight and NAFLD participants, with different molecular approaches from other studies. If our strategy works, it can contribute to improving the rationale of new studies considering the solutions proposed ahead. Despite our objectives being related to $\mathrm{w} 3$ actions in NAFLD patients, the original studies included in our protocol were selected from cardiovascular outcomes, as this was the most investigated area of study, which contained an appropriate sample size to demonstrate and achieve statistical significance. In addition, many of these studies used similar dosages of $\omega 3$ allowing comparisons among studies.

The EPA and DHA are the most studied among $\omega 3$ species; however, this remains without any standardization related to its origin, whether from flesh fish or capsules. De Mello et al. (2009) [58] compared the effect of fatty vs lean fish intake on inflammatory markers in patients with coronary heart disease. After 8 weeks, no differences were found between the groups. The authors used six types of fatty fishes (salmon, rainbow trout, Baltic herring, tuna, whitefish, or vendace); however, the fish's flesh fatty acid profile was not determined before the intervention, and the variation can be high among them. In fishes such as trout (Oncorhynchus mykiss) and salmon (Salmo salar), DHA is the primary $\omega 3$ prevalent type in the whole body, although fatty acids are distributed differently among their tissues. Betancor et al. (2017) [59] tested different diets for salmons and found in the control group (wild type) $6.8 \%$ of DHA in the flesh, similar to $6.2 \%$ in the flesh of rainbow trout found by Cintra et al. (2006) [60]. Despite being considered as fatty fishes, the lipid depots are out of the muscle, undisputedly the most used part in studies with humans. Betancor et al. (2017) [59] also found $25 \%$ of DHA in the liver of salmon, similar to the $27 \%$ on trout observed by Satué et al. (1996) [61]. Other conditions hard to control for are the fish gender [61] and stage of sexual maturation [62], both of which influence the fatty acid composition in all of the fish parts.

Considering these difficulties, we will adopt $\omega 3$ supplementation by capsules, even though there are several considerations to be noticed. One struggling question among the studies is the lack of oil quality monitoring in capsules $[57,63]$. We previously tested some supplement brands, choosing the one with the highest similarity to the natural profile found in wild fishes from cold water. The capsules were submitted to fatty acid profile determination by a gas-chromatography coupled to a mass spectrometer, an approach considered the gold standard, and should be obligatory before interventions due to routine adulteration $[63,64]$. In our study, we had access to the pharmaceutical company and traced the capsules, following the encapsulation process, since their origin (including placebo [mineral oil] capsules). The fresh 
capsules will also be tested a day before the beginning of the study.

Dose determination of $\omega 3$ supplement is as important as its quality. No standardized dose has been used in the literature and most of the doses used are considered very high. It is common to find well-controlled trials using $\omega 3$ associated or not with beneficial effects, under low or high doses. Considering low $\omega 3$ doses, a recently randomized placebo-controlled trial showed 12.933 participants treated with $840 \mathrm{mg} /$ day of $\omega 3$ capsules (EPA 460 $\mathrm{mg}$ and DHA $380 \mathrm{mg}$ ) during 5.3 years, aiming for primary prevention (myocardial infarction, stroke, and cardiovascular mortality) [29]. The authors did not find evidence of the differences in outcomes of major cardiovascular events. On the other hand, the GISSIPrevenzione Trial tested in 2.836 patients, a very similar $\omega 3$ dose (850 mg EPA+DHA/day [1:2]) during 3.5 years, and found a reduced rate of death, non-fatal myocardial infarction, and stroke [65]. When $\omega 3$ doses were increased, the same incongruences (major cardiovascular events) were noticed. Sixteen mild-hypertension patients taking two daily $\omega 3$ capsules (each capsule containing EPA $460 \mathrm{mg}$ and DHA $380 \mathrm{mg}$ ), during 3 months, did not have their blood pressure altered after treatment [66], while another study followed 23 hypertensive patients using $4 \mathrm{~g} /$ day $\omega 3$ (each capsule containing EPA $465 \mathrm{mg}$ and DHA $375 \mathrm{mg}$ ) during 2 months, found a very significant reduction on systolic $(P<0.03)$ and diastolic $(P<0.003)$ blood pressure [67]. Here, we decided to use $2.2 \mathrm{~g}$ of $\omega 3$ (3 capsules, $1 \mathrm{~g}$ each, containing EPA 190 $\mathrm{mg}$ and DHA $550 \mathrm{mg}$, Table 1), an intermediary $\omega 3$ dose found in relevant studies [34, 68].

Still regarding the dosage, the EPA: DHA blend is another non-standard characteristic presenting several divergent results when EPA or DHA is predominant [12, $69,70,71]$. The difficulty in this interpretation is worsening once a recent study showed the prominent and very consistent reduction in the risk of ischemic events, cardiovascular death, and hypertriglyceridemia on 4.089 patients using $2 \mathrm{~g}$ of icosapent ethyl [21]. The icosapent ethyl is a highly purified $\omega 3$ from EPA (C20:5), differentiating itself because it contains two more carbons after the ester bond (C22:5). It is also important not to confound it with docosapentaenoic acid (DPA), which has the same number of carbons and double-bounds (C22: 5), without natural occurrence [21].

The nutrigenomic approaches have clarified relevant differences between EPA and DHA molecules. During 10 weeks, under experimental obesity and NAFLD induced by a high-fat diet, mice supplemented with EPA or DHA exhibited distinct transcriptomic responses in the liver and muscle. In advanced NAFLD (steatohepatitis associated with fibrosis marks), the DHA reduced genes encoding liver fibrosis and immune cell recruitment, while EPA increased genes associated with cell cycle renew, without affecting the DHA targets [72]. In steatotic Zucker rats (genetic model for obesity and comorbidities) supplemented with EPA or DHA for 8 weeks, both fatty acids were useful through different signaling pathways. The EPA reduced the hepatic gluconeogenesis by inhibiting the FoxO1 transcription factor into the nucleus, while DHA reduced the fatty acid synthase (FAS) enzyme independent of FoxO1 modulation [73]. Despite distinct EPA and DHA actions, the synergy between the two appears to be most effective for global health. ${ }^{73}$ Here, we chose the capsule containing a natural blend similar to what is found in fishes from cold water (Table 1).

Undisputedly, the wrong placebo selection is one of the most significant limitations to pair the comparisons. Oils such as corn, sunflower, and safflower are exuberant sources of linoleic acid ( $\omega 6-\mathrm{C} 18: 2)$, without or with insignificant $\omega 3$ (ALA-C18:3) content [47]. Despite $\omega 6$ being an essential fatty acid, its excess could induce inflammation due to high prostaglandins $\left(\mathrm{PGE}_{2}, \mathrm{PGI}_{2}\right.$, $\mathrm{TXA}_{2}$ ) bioconversion [74, 75]. The relevance of $\omega 6: \omega 3$ ratio is currently questionable; however, it is still recommended to maintain this proportion around 5:1 ( $\omega 6: \omega 3)$. In western or highly industrialized societies, 20:1 is pointed as a risk to diseases with an inflammatory background [76]. Then, the use of $\omega 6$ sources as a placebo could overestimate the possible $\omega 3$ benefits $[67,77]$. On the other hand, olive oil has a broad spectrum of remarkable actions due to high oleic fatty acid (C18:1- $\omega 9)$ and phenolic compounds [78], underestimating the $\omega 3$ benefits. It is not an easy decision; however, molecular investigations have been contributing to reducing the probability of errors associated with fatty acid receptor homology.

The GPR40 is the receptor used by oleic fatty acid to control the intracellular inflammation cascade, similar to $\omega 3$, blocking TAK1 phosphorylation [79]; however, in humans, GPR 40 has 10\% of homology with GPR120 [80]. These receptors are promiscuous for both oleic and $\omega 3$ fatty acids, causing misinterpretation through crosstalk signaling [79]. After oleic cell entrance, it binds and activates the PGC1- $\alpha$ (PPAR- $\gamma$ Co-activator 1-alpha) protein, which induces the nuclear translocation of cMAF protein, a transcriptional factor responsible for interleukin-10 (IL10) gene transcription, the most potent anti-inflammatory interleukin [81]. Thus, through distinct manners, olive oil can mask the possible $\omega 3$ benefits $[30,34,66]$. Here, the mineral oil will be adopted because it has a low probability of interfering in the proposed outcomes or digestive emollient action at this dose [82].

GPR120 is the main $\omega 3$ receptor [17] present in several tissues [79], respondings rapidly when this molecule 
is present. Experimentally, 2, 3, or $4 \mathrm{~h}$ after administration of a single dose of a rich $\omega 3$ source (flaxseed oil), the GPR120 pathway was activated in the liver, muscle, adipose tissue [79], aorta [42], and retina [41] of obese and insulin-resistant mice. In comparison to the placebo, the $\omega 3$-treated group had the Barr2 attracted to GPR120. So far, this approach has not been tested in humans and could reflect the acute action of $\omega 3$ fatty acids, and its undescribed antiinflammatory detailed mechanism. We do not expect a reduction in inflammatory markers acutely (after 3 or $4 \mathrm{~h}$ ); however, if GPR120 will bind to ßarr2, the existence of this possibility will be firstly evidenced in humans. The choice for peripheral blood mononuclear cells (PBMCs) was supported by two studies that identified the presence of GPR120 on macrophage surface infiltered in mice aorta [42] and on Kupffer cells in the liver [83]. Raptis et al. (2014) showed the $\omega 3$ anti-inflammatory action through TAK1 inhibition, mediated by ßarr2 connected to GPR120, which changed the Kupffer polarization from M1 to M2 phenotype, mitigating inflammatory stress in the liver [83].

After acute $\omega 3$ testing, subjects will be supplemented with $\omega 3$ or placebo for 4 weeks, in accordance to JiménezGómez et al. (2009) [84] and Ras et al. (2014) [85], who respectively showed the reduction on IL6 mRNA content in PBMCs or reduction on hypertriglyceridemic and hypercholesterolemic patients treated with $\omega 3$ in capsules during 4 weeks. Not distant, the ER-stress response is intimately connected to inflammatory signaling, counterbalance inflammation, and apoptosis [4, 13, 42]. In hepatocytes, ER stress has a remarkable capacity to adapt to extracellular and intracellular changes to ensure that vital hepatic metabolic functions are preserved. However, in humans, numerous disturbances (e.g., hyperlipidemia, inflammation, drugs) can disturb the hepatocyte ER homeostasis contributing to hepatic lipid metabolism dysregulation and liver disease [86]. Mozzini et al. (2014) [87] described a correlation between ER-stress in PBMC and coronary artery disease. In this sense, we decided to test this correlation in NAFLD subjects and its possible reversal after $\omega 3$ supplementation.

GPR120 variation, a non-synonymous mutation (p.R270H), has been associated with obesity in humans [36]. To study such mutations/polymorphisms, large sample size is needed. Although this trial has a few numbers of participants to test for mutations, a test of the GPR120 variation will be conducted to guarantee all known aspects that may be associated with the GPR120 functioning.

Thus, considering the lack of conclusive data regarding the $\omega 3$ fatty acid in mediating the resolution of inflammation and its consequences through GPR120 in immune cells of overweight/obese and NAFLD individuals, the present study is crucial for the characterization of the signaling mechanisms and molecules that mediate these effects.

\section{Strengths and limitations of study design}

The strengths of this study include the triple blinding (participants, investigators, and statistical analyst), the $\omega 3$ and placebo capsules quality being monitored from the factory development to the blood serum bioavailability and $\omega 3$ PBMC incorporation. Limitations include patients taking statins, as the pleiotropic beneficial effects of statin could mask the $\omega 3$ benefits.

\section{Abbreviations}

Barr2: Beta-arrestin 2; w3: Omega-3; ATF: Activating transcription factor: CHOP: C/EBP homologous protein; DHA: Docosahexaenoic acid; elF: Eukaryotic initiation factor; EPA: Eicosapentaenoic acid; FFAR: Free fatty acid receptor; GPR120: G-protein-coupled receptor-120; HSP: Heat shock protein; IL: Interleukin; IRE: Inositol-requiring enzyme; JNK: c-JUN N-terminalkinase; MCP1: Monocytes chemoattractant protein 1; NAFLD: Non-alcoholic fatty liver disease; NLPR3: NOD-, LRR-, and pyrin domain-containing protein 3; PBMC: Peripheral blood mononuclear cells; PPARg: Peroxisome

proliferator-activated receptor-gamma; TAB1: Mitogen-activated protein kinase kinase kinase 7-interacting protein 1; TAK: TGF $\beta$-activated kinase1; TLR4: Toll-like receptor-4; TNF: Tumor necrosis factor; UPR: Unfolded protein response; XBP1: X-box binding protein 1

\section{Supplementary Information}

The online version contains supplementary material available at https://doi. org/10.1186/s13063-021-05702-x.

Additional file 1:. Standard Protocol Items: Recommendation for Intervention Trials (SPIRIT)

\section{Acknowledgements}

We would like to acknowledge the following contributors: Dr. Rezende N.A, for participants' randomization; Obesity Comorbidities Research Center (OCRC) - FAPESP to support part of this study with grant \#2013/07607-8, Fundação de Amparo à Pesquisa do Estado de São Paulo (FAPESP) with the grant \#2012/07129-6. Related to fundings, we highlighted that FAPESP is a statal foundation, without profit interests.

\section{Protocol amendments}

The amendments will not change the original characteristics of the study. Any amendments will be immediately reported to the Ethics Committee of our institution (CEP/CONEP system) from "Brazil Platform" and the REBEC (The Brazilian Clinical Trials Registry). The amendments will be implemented only after the Ethics Committee agreement. All outpatients will be informed by the amendments before signing the new informed consent form. These amendments are limited to the inevitable necessity to increase the total amount of blood collection or, in the future, some eventual new genotyping analysis.

\section{Trial status}

Protocol Version 1, October 10, 2019. Recruitment is completed. The analysis is ongoing, started November 10,2020, with estimated completion November 12, 2021

\section{Dissemination plans}

The study results will be presented in scientific meetings and publications in medical journals. The trial will be reported according to the Standard

Protocol Items: Recommendation for Intervention Trials (SPIRIT)

(Supplemental file 1).

Oversight and monitoring 


\section{Composition of the coordinating center and trial steering committee} Both institutions, the University of Campinas (UNICAMP) and the Federal University of Sergipe (UFS) are co-responsible for the study. The Principal Investigator (Cintra DE) and the second Principal Investigator (Camargo EA) are largely responsible for the running of the research project and supervision of the doctoral fellow (Batista ES).

A steering committee comprise MD-Ph.D Lício Augusto Velloso, from the University of Campinas, and two lipidologists, Ph.D. Ana Maria Pita Lottenberg, from Faculty of Medicine of the University of São Paulo, and Ph.D. Nágila Damasceno, from the Public Health School of the University of São Paulo. Briefly, from the steering committee is expected the independent audits for plans and results, reviewing processes for risk management, and the processes for complying with laws and regulations.

\section{Composition of the data monitoring committee, its role, and reporting} structure

Data monitoring will be undertaken by the trial management group: DEC, $E A C$, and the doctoral fellow ESB. Given that the researchers are blind to allocation, data monitoring will occur solely to ensure data quality and adherence to the study protocol. The blinding, randomization, and unblinding of patients and biological samples will be carried out by Antônio Gomes Rezende Neto, Ph.D., which is an associated researcher to the health sciences post-graduation program from the Federal University of Sergipe. Dr. Antônio is an external member of the study, without any connection with our research groups.

\section{Institutions responsible for the study}

Both institutions, the University of Campinas and the Federal University of Sergipe, are legally co-responsible by the current study.

\section{Authors' contributions}

DEC and EAC are the chief investigators and conceived the study; ESB recruited the patients; EBS, VRM, and JJS developed the analysis; VMM, SRCBN, and TR ran the Western blots and RT-qPCR analysis; DTC developed the statistical plan for the study. JMR and RL: developed the food frequency questionary analysis. ASRS, JRP, ERR, and LPM conceived molecular biology experiments, provided the reagents, and analyzed the results. RAM reviewed the protocols and contributed to the rationale of the experimental design. DEC and ESB wrote the paper. All authors read and approved the final manuscript.

\section{Availability of data and materials \\ Not applicable.}

\section{Ethics approval and consent to participate}

This study will be conducted with the highest respect for volunteers. We followed the Declaration of Helsinki and the Ethical Guidelines for Clinical Research. This study was approved by the Ethics Committee of the Federal University of Sergipe (\#80476517.2.0000.5546). Written informed consent (including for publication) was obtained before randomization in the usual manner.

\section{Competing interests}

None. The Naturalis company, an Omega-3 capsule factory, was chosen among many others, after the quality of their capsules be certified by our laboratory. The company did not ask for the results, does not know anyone from the study, and did not participate in any other aspect of this study. Nor Naturalis company neither the FAPESP funder will audit the study at any time. Thus, the authors declare that they have no competing interests.

\section{Author details}

'Graduate Program of Health Sciences (PPGCS), Federal University of Sergipe, Aracaju, Sergipe, Brazil. ${ }^{2}$ Laboratory of Nutritional Genomics, School of Applied Sciences, University of Campinas, Pedro Zaccaria, 1300 Zip, Limeira 13484-350, Brazil. ${ }^{3}$ Nutrition Department, Federal University of Sergipe, Lagarto, Sergipe, Brazil. " Lipids and Nutrigenomics Research Center, School of Applied Sciences, University of Campinas, Limeira, Brazil. ${ }^{5}$ Laboratory of Molecular Biology of Exercise, School of Applied Sciences, University of Campinas, Limeira, Brazil. " $M$ Multidisciplinary Laboratory of Food and Health, School of Applied Sciences, University of Campinas, Limeira, Brazil. ${ }^{7}$ Department of Integrated Health Education, Federal University of Espírito
Santo, Vitoria, Brazil. ${ }^{8}$ School of Physical Education and Sport of Ribeirão Preto, University of São Paulo (USP), Ribeirão Preto, São Paulo, Brazil. ${ }^{9}$ Massachusetts College of Pharmacy and Health Sciences (MCPHS) University, Boston, MA, USA. ${ }^{10}$ Department of Neurosurgery, Brigham and Women's Hospital, Harvard Medical School, Boston, MA, USA. ${ }^{11}$ Department of Physiology, Federal University of Sergipe, São Cristóvão, Sergipe, Brazil.

Received: 30 March 2021 Accepted: 8 October 2021

Published online: 18 December 2021

\section{References}

1. Peter D. Gluckman, Mark Hanson, Paul Zimmet. T. F. Losing the war against obesity: the need for a developmental perspective. Sci Trans/ Med. 2011: 3(93):1-4. https://doi.org/10.1126/scitransImed.3002554.

2. Amor I. Ben et al. Midterm outcomes of gastric pouch resizing for weight regain after roux-en-Y gastric bypass. Obes. Surg. 2020;30(7):2723-8. https:// doi.org/10.1007/s11695-020-04560-x.

3. Van De Sande-Lee $S$, et al. Partial reversibility of hypothalamic dysfunction and changes in brain activity after body mass reduction in obese subjects. Diabetes. 2011;60(6):1699-704. https://doi.org/10.2337/db10-1614.

4. Cintra DE, Ropelle ER, Moraes JC, Pauli JR, Morari J, de Souza CT, et al. Unsaturated fatty acids revert diet-induced hypothalamic inflammation in obesity. PLoS One. 2012;7(1):e30571. https://doi.org/10.1371/journal.pone.003 0571.

5. Thaler JP, Yi CX, Schur EA, Guyenet SJ, Hwang BH, Dietrich MO, et al. Obesity is associated with hypothalamic injury in rodents and humans. J. Clin. Invest. 2012;122(1):153-62. https://doi.org/10.1172/JCl59660.

6. Smith Gl, Shankaran M, Yoshino M, Schweitzer GG, Chondronikola M, Beals JW, et al. Insulin resistance drives hepatic de novo lipogenesis in nonalcoholic fatty liver disease. J. Clin. Invest. 2020;130(3):1453-60. https:// doi.org/10.1172/JCl134165

7. Odegaard, J. I. \& Chawla, A. Pleiotropic actions of insulin resistance and inflammation in metabolic homeostasis. Science (80-. ). 339, 172-177 (2013).

8. Catrysse L, van Loo G. Inflammation and the metabolic syndrome: the tissue-specific functions of NF-kB. Trends Cell Biol. 2017;27(6):417-29. https:// doi.org/10.1016/j.tcb.2017.01.006.

9. Hernández EA, Kahl S, Seelig A, Begovatz P, Irmler M, Kupriyanova Y, et al. Acute dietary fat intake initiates alterations in energy metabolism and insulin resistance. J. Clin. Invest. 2017;127(2):695-708. https://doi.org/10.1172/ JCl89444.

10. Kado A, Tsutsumi T, Enooku K, Fujinaga H, Ikeuchi K, Okushin K, et al. Noninvasive diagnostic criteria for nonalcoholic steatohepatitis based on gene expression levels in peripheral blood mononuclear cells. J. Gastroenterol. 2019;54(8):730-41. https://doi.org/10.1007/s00535-019-01565-x.

11. Myhrstad MCW, Ulven SM, Günther CC, Ottestad I, Holden M, Ryeng E, et al. Fish oil supplementation induces expression of genes related to cell cycle, endoplasmic reticulum stress and apoptosis in peripheral blood mononuclear cells: a transcriptomic approach. J. Intern. Med. 2014;276(5): 498-511. https://doi.org/10.1111/joim.12217.

12. Vedin I, Cederholm T, Freund-Levi Y, Basun H, Garlind A, Irving GF, et al. Effects of DHA- rich n-3 fatty acid supplementation on gene expression in blood mononuclear leukocytes: the omegAD study. PLoS One. 2012;7(4): e35425. https://doi.org/10.1371/journal.pone.0035425.

13. Hotamisligil GS. Inflammation, metaflammation and immunometabolic disorders. Nature. 2017;542(7640):177-85. https://doi.org/10.1038/nature213 63.

14. Reilly SM, Saltiel AR. Adapting to obesity with adipose tissue inflammation. Nat. Rev. Endocrinol. 2017;13(11):633-43. https://doi.org/10.1038/nrendo.201 7.90 .

15. H, A. Elevated serum TNF- $a$ is related to obesity in type 2 diabetes mellitus and is associated with glycemic control and insulin resistance. J. Obes. 2020, (2020).

16. Shi G, Maminishkis A, Banzon T, Jalickee S, Li R, Hammer J, et al. Control of chemokine gradients by the retinal pigment epithelium. Invest. Ophthalmol. Vis. Sci. 2008:49(10):4620-30. https://doi.org/10.1167/iovs.08-1816.

17. Oh DY, Talukdar S, Bae EJ, Imamura T, Morinaga H, Fan WQ, et al. GPR120 is an Omega-3 fatty acid receptor mediating potent anti-inflammatory and insulin-sensitizing effects. Cell. 2010;142(5):687-98. https://doi.org/10.1016/j. cell.2010.07.041.

18. Zayed EA, AinShoka AA, El Shazly KA, Abd El Latif HA. Improvement of insulin resistance via increase of GLUT4 and PPARY in metabolic syndrome- 
induced rats treated with omega-3 fatty acid or I-carnitine. J. Biochem. Mol. Toxicol. 2018;32

19. Daniel H. Hwanga, Jeong-A. Kimb, J. Y. L. Mechanisms for the activation of Toll-like receptor $2 / 4$ by saturated fatty acids and inhibition by docosahexaenoic acid. Eur J Pharmacol. 2016;15:24-35. https://doi.org/10.1 016/.ejphar.2016.04.024.

20. Huang F, del-Río-Navarro BE, Leija-Martinez J, Torres-Alcantara S, RuizBedolla $E$, Hernández-Cadena $L$, et al. Effect of omega-3 fatty acids supplementation combined with lifestyle intervention on adipokines and biomarkers of endothelial dysfunction in obese adolescents with hypertriglyceridemia. J. Nutr. Biochem. 2019;64:162-9. https://doi.org/10.101 6/j.jnutbio.2018.10.012.

21. Bhatt DL, Steg PG, Miller M, Brinton EA, Jacobson TA, Ketchum SB, et al. Cardiovascular risk reduction with icosapent ethyl for hypertriglyceridemia. N. Engl. J. Med. 2019;380(1):11-22. https://doi.org/10.1056/NEJMoa1812792.

22. Albracht-Schulte K, Kalupahana NS, Ramalingam L, Wang S, Rahman SM, Robert-McComb J, et al. Omega-3 fatty acids in obesity and metabolic syndrome: a mechanistic update. J. Nutr. Biochem. 2018;58:1-16. https://doi. org/10.1016/j.jnutbio.2018.02.012.

23. Dyerberg J, Bang HO, Stoffersen E, Moncada S, Vane JR. Eicosapentaenoic acid and prevention of thrombosis and atherosclerosis? Lancet (London, England) 2, 117-9; 1978.

24. Dyerberg J, Bang HO. Haemostatic function and platelet polyunsaturated fatty acids in Eskimos. Lancet (London, England). 1979;2:433-5.

25. Hirasawa A, Tsumaya K, Awaji T, Katsuma S, Adachi T, Yamada M, et al. Free fatty acids regulate gut incretin glucagon-like peptide-1 secretion through GPR120. Nat. Med. 2005;11(1):90-4. https://doi.org/10.1038/nm1168.

26. Yan Y, Jiang W, Spinetti T, Tardivel A, Castillo R, Bourquin C, et al. Omega-3 fatty acids prevent inflammation and metabolic disorder through inhibition of NLRP3 inflammasome activation. Immunity. 2013;38(6):1154-63. https:// doi.org/10.1016/j.immuni.2013.05.015.

27. Duvall MG, Levy BD. Airway inflammation. Chest. 1998;114:290S.

28. Charles N. Serhan, Jesmond Dalli, Romain A. Colas, Jeremy W. Winkler, and N. C. Protectins and maresins: new pro-resolving families of mediators in acute inflammation and resolution bioactive metabolome. Biochim Biophys Acta. 2015;185(4):397-413. https://doi.org/10.1016/.bbalip.2014.08.006.

29. Manson JAE, et al. Marine $\mathrm{n}-3$ fatty acids and prevention of cardiovascular disease and cancer. N. Engl. J. Med. 2019;380(1):23-32. https://doi.org/10.1 056/NEJMoa1811403.

30. Bowman $L$, et al. Effects of $n-3$ fatty acid supplements in diabetes mellitus. N. Engl. J. Med. 2018;379(16):1540-50. https://doi.org/10.1056/NEJMoa1804 989.

31. Arnett DK, Blumenthal RS, Albert MA, Buroker AB, Goldberger ZD, Hahn EJ, et al. 2019 ACC/AHA Guideline on the primary prevention of cardiovascular disease: executive summary. J. Am. Coll. Cardiol. 2019;74(10):1376-414. https://doi.org/10.1016/j.jacc.2019.03.009.

32. Santos RD, Gagliardi AC, Xavier HT, Magnoni CD, Cassani R, Lottenberg AM, et al. First guidelines on fat consumption and cardiovascular health. Arq. Bras. Cardiol. 2013;100(1 Suppl 3):1-40.

33. Araujo $P$, Tilahun E, Zeng Y. A novel strategy for discriminating marine oils by using the positional distribution (sn-1, sn-2, sn-3) of omega-3 polyunsaturated fatty acids in triacylglycerols. Talanta. 2018;182:32-7. https://doi.org/10.1016/.talanta.2018.01.030.

34. Kastelein JJP, Maki KC, Susekov A, Ezhov M, Nordestgaard BG, Machielse BN, et al. Omega-3 free fatty acids for the treatment of severe hypertriglyceridemia: the EpanoVa for lowering very high triglyceridEs (EVOLVE) trial. J. Clin. Lipidol. 2014;8(1):94-106. https://doi.org/10.1016/j.jacl.2013.10.003.

35. Gerling CJ, Whitfield J, Mukai K, Spriet LL. Variable effects of 12 weeks of omega-3 supplementation on resting skeletal muscle metabolism. Appl. Physiol. Nutr. Metab. 2014;39(9):1083-91. https://doi.org/10.1139/apnm-2014-0049.

36. Ichimura A, Hirasawa A, Poulain-Godefroy O, Bonnefond A, Hara T, Yengo L, et al. Dysfunction of lipid sensor GPR120 leads to obesity in both mouse and human. Nature. 2012;483(7389):350-4. https://doi.org/10.1038/nature10798.

37. Chan AW, Tetzlaff JM, Altman DG, Laupacis A, Gøtzsche PC, Krleža-Jerić K, et al. SPIRIT 2013 statement: defining standard protocol items for clinical trials. Annals of Internal Medicine. 2013;158(3):200-7. https://doi.org/10.7326/ 0003-4819-158-3-201302050-00583.

38. Organization, W. H WHO_NUT_NCD_98.1_(p1-158).pdf. 275 (1997).

39. Huang S-S, He S-L, Zhang Y-M. The effects of telmisartan on the nuclear factor of activated T lymphocytes signalling pathway in hypertensive patients. J. Renin. Angiotensin. Aldosterone. Syst. 2016;17:1470320316655005.
40. da Saúde M. Vigitel Brasil 2018: Vigilância de fatores de risco e proteção para doenças crônicas por inquerito telefônico. G. Estatística e Informação em Saúde. 2019.

41. Dátilo, M. N. et al. Omega-3 from flaxseed oil protects obese mice against diabetic retinopathy through GPR120 receptor. 1-13 (2018). doi:https://doi. org/10.1038/s41598-018-32553-5

42. Moura-Assis A, Afonso MS, de Oliveira V, Morari J, dos Santos GA, Koike M, et al. Flaxseed oil rich in Omega-3 protects aorta against inflammation and endoplasmic reticulum stress partially mediated by GPR120 receptor in obese, diabetic and dyslipidemic mice models. J. Nutr. Biochem. 2018:53:919. https://doi.org/10.1016/j.jnutbio.2017.09.015.

43. NHANES. Anthropometry procedures manual. Natl. Heal. Nutr. examinatory Surv. 1-102 (2007)

44. Sarry El Din, A., Hassan, N., El-Masry, S. \& Al-Tohamy, M. Neck circumference as a simple screening measure for identifying Egyptian overweight and obese adults. Maced. J. Med. Sci. 6, 232-237 (2013).

45. Ashwell M, Hsieh SD. Six reasons why the waist-to-height ratio is a rapid and effective global indicator for health risks of obesity and how its use could simplify the international public health message on obesity. Int. J. Food Sci. Nutr. 2005;56(5):303-7. https://doi.org/10.1080/09637480500195066.

46. Durnin, B. Y. J. V. G. a \& Womersley, J. Body fat assessed from total body density and its estimation from skinfold thickness: measurements on 481 men and womwn aged from 16 to 72 years. Br. J. Nutr. 32, 77-97 (1973).

47. NEPA. TACO. Public domain 164 (2011). Available at: http://www.nepa.unica mp.br/taco/tabela.php?ativo=tabela. (Accessed: 18th June 2020)

48. IBGE. Brazilian Institute of Geography and Statistics. Demographic Census. (2010). Available at: https://censo2010.ibge.gov.br/. (Accessed: 7th September 2020)

49. Nusser SM, Carriquiry AL, Dodd KW, Fuller WA. A semiparametric transformation approach to estimating usual daily intake distributions. J. Am. Stat. Assoc. 1996;91(436):1440-9. https://doi.org/10.1080/01621459.1 996.10476712

50. Willett W, Stampfer MJ. Total energy intake: implications for epidemiologic analyses. Am. J. Epidemiol. 1986;124(1):17-27. https://doi.org/10.1093/ oxfordjournals.aje.a114366.

51. Matsudo S, et al. Questionário Internacional De Atividade Física (Ipaq): Estupo De Validade E Reprodutibilidade No Brasil. Rev. Bras. Atividade Física Saúde. 2012;6:5-18.

52. Krogulska A, Borowiec M, Polakowska E, Dynowski J, Młynarski W, Wasowska-Królikowska K. FOXP3, IL-10, and TGF- $\beta$ genes expression in children with IgE-dependent food allergy. J. Clin. Immunol. 2011;31(2):20515. https://doi.org/10.1007/s10875-010-9487-1.

53. Muñoz VR, Gaspar RC, Kuga GK, da Rocha AL, Crisol BM, Botezelli JD, et al. Exercise increases Rho-kinase activity and insulin signaling in skeletal muscle. J. Cell. Physiol. 2018:233(6):4791-800. https://doi.org/10.1002/jcp.26278.

54. Hartman, L. \& Lago, R. C. Rapid preparation of fatty acid methyl esters from lipids. Lab. Pract. 22, 475-476 passim (1973).

55. Shirai N, Suzuki H, Wada S. Direct methylation from mouse plasma and from liver and brain homogenates. Anal. Biochem. 2005;343(1):48-53. https://doi.org/10.1016/j.ab.2005.04.037.

56. McCoy CE. Understanding the intention-to-treat principle in randomized controlled trials. Western Journal of Emergency Medicine. 2017;18(6):1075-8. https://doi.org/10.5811/westjem.2017.8.35985.

57. Wang DD, Hu FB. Dietary fat and risk of cardiovascular disease: recent controversies and advances. Annu. Rev. Nutr. 2017:37(1):423-46. https://doi. org/10.1146/annurev-nutr-071816-064614.

58. De Mello VDF, et al. The effect of fatty or lean fish intake on inflammatory gene expression in peripheral blood mononuclear cells of patients with coronary heart disease. Eur. J. Nutr. 2009;48(8):447-55. https://doi.org/10.1 007/s00394-009-0033-y.

59. Betancor MB, et al. An oil containing EPA and DHA from transgenic Camelina sativa to replace marine fish oil in feeds for Atlantic salmon (Salmo salar L.): effects on intestinal transcriptome, histology, tissue fatty acid profiles and plasma biochemistry. PLoS One. 2017;12.

60. Cintra DEC, Costa AGV, Peluzio MCG, Matta SLP, Silva MTC, Costa NMB. Lipid profile of rats fed high-fat diets based on flaxseed, peanut, trout, or chicken skin. Nutrition. 2006;22(2):197-205. https://doi.org/10.1016/j. nut.2005.09.003.

61. Satué MT, López MC. Sex-linked differences in fatty acid composition of rainbow trout (Oncorhynchus mykiss) liver oil. Food Chem. 1996;57(3):35963. https://doi.org/10.1016/0308-8146(95)00235-9. 
62. Ribeiro CS, Gomes AD, Vieira VARO, Tabata YA, Takahashi NS, Moreira RG The effect of ploidy on the fatty acid profile during the reproductive cycle of female rainbow trout (Oncorhynchus mykiss). Aquac. Int. 2012;20(6):111737. https://doi.org/10.1007/s10499-011-9468-2.

63. Ritter JCS, Budge SM, Jovica F. Quality analysis of commercial fish oil preparations. J. Sci. Food Agric. 2013;93(8):1935-9. https://doi.org/10.1002/ jsfa.5994.

64. Galuch $M$, et al. Quality assessment of Omega-3 supplements available in the Brazilian market. J. Braz. Chem. Soc. 2017;29:631-8.

65. Gruppo Gl. Dietary supplementation with n-3 polyunsaturated fatty acids and vitamin E after myocardial infarction: results of the GISSI-Prevenzione trial. Gruppo Italiano per lo Studio della Sopravvivenza nell'Infarto miocardico. Lancet (London, England). 1999;354:447-55.

66. Hande LN, Thunhaug H, Enebakk T, Ludviksen J, Pettersen $K$, Hovland A, et al. Addition of marine omega-3 fatty acids to statins in familial hypercholesterolemia does not affect in vivo or in vitro endothelial function. J. Clin. Lipidol. 2019;13(5):762-70. https://doi.org/10.1016/j.jacl.2019. 08.004 .

67. Skulas-Ray AC, Kris-Etherton PM, Harris WS, West SG. Effects of marinederived omega-3 fatty acids on systemic hemodynamics at rest and during stress: a dose-response study. Ann. Behav. Med. 2012:44(3):301-8. https://doi. org/10.1007/s12160-012-9393-2.

68. Nodari S, Triggiani M, Campia U, Manerba A, Milesi G, Cesana BM, et al. Effects of $n-3$ polyunsaturated fatty acids on left ventricular function and functional capacity in patients with dilated cardiomyopathy. J. Am. Coll. Cardiol. 2011;57(7):870-9. https://doi.org/10.1016/j.jacc.2010.11.017.

69. Klingel, SL; Metherel, AH; Irfan, M; Rajna, A; Chabowski, A; Bazinet, RP; Mutch, D. EPA and DHA have divergent effects on serum triglycerides and lipogenesis, but similar effects on lipoprotein lipase activity: a randomized controlled trial - PubMed. 1502-1509 (2019).

70. Vors C, Allaire J, Marin J, Lépine MC, Charest A, Tchernof A, et al. Inflammatory gene expression in whole blood cells after EPA vs. DHA supplementation: results from the ComparED study. Atherosclerosis. 2017; 257:116-22. https://doi.org/10.1016/j.atherosclerosis.2017.01.025.

71. Mozaffarian D, Wu JHY. (n-3) Fatty acids and cardiovascular health: are effects of EPA and DHA shared or complementary? J. Nutr. 2012;142.

72. Kunz HE, Dasari S, Lanza IR. EPA and DHA elicit distinct transcriptional responses to high-fat feeding in skeletal muscle and liver. Am. J. Physiol. Endocrinol. Metab. 2019;317(3):E460-72. https://doi.org/10.1152/ajpendo. 00083.2019 .

73. Hong L, Zahradka P, Cordero-Monroy L, Wright B, Taylor CG. Dietary docosahexaenoic acid (DHA) and eicosapentaenoic acid (EPA) operate by different mechanisms to modulate hepatic steatosis and hyperinsulemia in fa/fa Zucker rats. Nutrients. 2019;11(4). https://doi.org/10.3390/nu11040917.

74. Kain V, Ingle KA, Kachman M, Baum H, Shanmugam G, Rajasekaran NS, et al. Excess $\omega-6$ fatty acids influx in aging drives metabolic dysregulation, electrocardiographic alterations, and low-grade chronic inflammation. Am. J. Physiol. - Hear. Circ. Physiol. 2018;314(2):H160-9. https://doi.org/10.1152/a jpheart.00297.2017.

75. Rallidis, L. S. et al. Dietary a -linolenic acid decreases C-reacti v e protein , serum amyloid A and interleukin-6 in dyslipidaemic patients. 167, (2003).

76. Simopoulos AP. An increase in the Omega-6/Omega-3 fatty acid ratio increases the risk for obesity. Nutrients. 2016;8(3):1-17. https://doi.org/10.33 90/nu8030128.

77. Rodríguez-Cruz M, Cruz-Guzmán OR, Almeida-Becerril T, Solís-Serna AD, Atilano-Miguel S, Sánchez-González JR, et al. Potential therapeutic impact of omega-3 long chain-polyunsaturated fatty acids on inflammation markers in Duchenne muscular dystrophy: a double-blind, controlled randomized trial. Clin. Nutr. 2018;37(6):1840-51. https://doi.org/10.1016/j.clnu.2017.09.011.

78. Estruch $\mathrm{R}$, et al. Primary prevention of cardiovascular disease with a mediterranean diet supplemented with extra-virgin olive oil or nuts. N. Engl. J. Med. 2018;378:1-14.

79. Oliveira V, Marinho R, Vitorino D, Santos GA, Moraes JC, Dragano N, et al. Diets containing a-Linolenic ( $\omega 3$ ) or Oleic ( $\omega 9)$ fatty acids rescues obese mice from insulin resistance. Endocrinology. 2015;156(11):4033-46. https:// doi.org/10.1210/en.2014-1880.

80. Hirasawa A, Hara T, Katsuma S, Adachi T, Tsujimoto G. Free fatty acid receptors and drug discovery. Biol. Pharm. Bull. 2008;31(10):1847-51. https:// doi.org/10.1248/bpb.31.1847.

81. Morari J, Torsoni AS, Anhê GF, Roman EA, Cintra DE, Ward LS, et al. The role of proliferator-activated receptor $\gamma$ coactivator-1a in the fatty-acid- dependent transcriptional control of interleukin-10 in hepatic cells of rodents. Metabolism. 2010;59(2):215-23. https://doi.org/10.1016/j.metabol.2 009.07.020.

82. Nogueira MA, Oliveira CP, Ferreira Alves VA, Stefano JT, Rodrigues LSR, Torrinhas RS, et al. Omega-3 polyunsaturated fatty acids in treating nonalcoholic steatohepatitis: a randomized, double-blind, placebo-controlled trial. Clin. Nutr. 2016;35(3):578-86. https://doi.org/10.1016/j.clnu.2015.05.001.

83. Raptis DA, Limani P, Jang JH, Ungethüm U, Tschuor C, Graf R, et al. GPR120 on Kupffer cells mediates hepatoprotective effects of $\omega 3$-fatty acids. J. Hepatol. 2014;60(3):625-32. https://doi.org/10.1016/j.jhep.2013.11.006.

84. Jiménez-Gómez Y, López-Miranda J, Blanco-Colio LM, Marín C, PérezMartínez P, Ruano J, et al. Olive oil and walnut breakfasts reduce the postprandial inflammatory response in mononuclear cells compared with a butter breakfast in healthy men. Atherosclerosis. 2009;204(2):70-6. https://doi. org/10.1016/j.atherosclerosis.2008.09.011.

85. Ras RT, Demonty I, Zebregs YEMP, Quadt JFA, Olsson J, Trautwein EA. Low doses of eicosapentaenoic acid and docosahexaenoic acid from fish oil dose- dependently decrease serum triglyceride concentrations in the presence of plant sterols in hypercholesterolemic men and women. J. Nutr. 2014;144(10):1564-70. https://doi.org/10.3945/jn.114.192229.

86. Lebeaupin C, Vallée D, Hazari Y, Hetz C, Chevet E, Bailly-Maitre B. Endoplasmic reticulum stress signalling and the pathogenesis of nonalcoholic fatty liver disease. Journal of Hepatology. 2018;69(4):927-47. https:// doi.org/10.1016/j.jhep.2018.06.008.

87. Mozzini C, Fratta Pasini A, Garbin U, Stranieri C, Pasini A, Vallerio P, et al. Increased endoplasmic reticulum stress and Nrf2 repression in peripheral blood mononuclear cells of patients with stable coronary artery disease. Free Radic. Biol. Med. 2014;68:178-85. https://doi.org/10.1016/j.freera dbiomed.2013.12.017.

\section{Publisher's Note}

Springer Nature remains neutral with regard to jurisdictional claims in published maps and institutional affiliations.
Ready to submit your research? Choose BMC and benefit from:

- fast, convenient online submission

- thorough peer review by experienced researchers in your field

- rapid publication on acceptance

- support for research data, including large and complex data types

- gold Open Access which fosters wider collaboration and increased citations

- maximum visibility for your research: over $100 \mathrm{M}$ website views per year

At BMC, research is always in progress.

Learn more biomedcentral.com/submissions 